\title{
Aspects related to production e storage of Tifton 85 bermudagrass hay with white oat IPR 126 and Guapa oversowing
}

\author{
Aspectos relacionados à produção e armazenamento do feno de \\ Tifton 85 com sobressemeadura de aveia branca IPR 126 e Guapa
}

\author{
João Paulo Ames ${ }^{1}$; Marcela Abbado Neres²*; Deise Dalazen Castagnara ${ }^{3}$; \\ Edleusa Pereira Seidel ${ }^{4}$; Camila Andrine Hunoff ${ }^{1}$; Camila Ducati ${ }^{1}$; \\ Jeferson Tiago Piano ${ }^{5}$; Ivaldir Willian Júnior Machado ${ }^{1}$
}

\begin{abstract}
Structural characteristics, curve dehydration, dry matter production, chemical composition, occurrence of fungi, temperature in the storage of hay bales of Tifton 85 oversowing with long-cycle oat (IPR 126) and oats for short-cycle grains production (Guapa), were evaluated. For chemical composition, the experimental design used was randomized blocks, a split-plot overtime and 3 treatments (single Tifton 85 , Tifton 85 with IPR 126 oat oversowing and Tifton 85 in association with Guapa white oat and 3 assessment periods (cutting, baling and 30 days of storage) with 5 repetitions. The dry matter production was higher in single Tifton 85 compared to associations with white oat. The largest stem diameter of guapa white oat contributed to reduce losses of water in the dehydration process, with the hay in this culture system being stored under $800 \mathrm{~g} \mathrm{~kg}^{-1} \mathrm{DM}$. It was found that the crude protein did not differ between cropping systems, but Tifton 85 hay showed high levels of acid detergent insoluble protein and higher levels of NDF and lignin. The occurrence of fungi was higher after storage predominating fungi of the genus Penicillium.
\end{abstract}

Key words: Avena sativa, storage fungi, Penicillium sp, neutral detergent insoluble protein

\section{Resumo}

Avaliou-se as características estruturais, curva de desidratação, produção de matéria seca, composição bromatológica, ocorrência de fungos, temperatura dos fardos no armazenamento do feno de capim tifton 85 sobressemeados com aveia branca de ciclo longo (IPR 126) e aveia branca para produção de grãos de ciclo curto (Guapa). Na composição bromatológica, o delineamento experimental foi de blocos casualizados com parcelas subdivididas no tempo com 3 tratamentos (tifton 85 solteiro, tifton 85 com sobressemeadura da aveia IPR 126 e tifton 85 em associação com aveia branca Guapa em 3 períodos de avaliação (corte, enfardamento e 30 dias de armazenamento), com 5 repetições. A produção de MS foi superior no tifton 85 solteiro quando comparado em associações com aveia. O maior diâmetro de colmo da aveia branca guapa contribuiu na redução das perdas de água por desidratação, sendo este

\footnotetext{
${ }^{1}$ Discentes de Mestrado do Programa de Pós Graduação em Nutrição e Produção Animal, Universidade Estadual do Oeste do Paraná, UNIOESTE, Marechal Cândido Rondon, PR, Brasil. E-mail: joaopauloames@yahoo.com.br; andzinha@hotmail.com; camila_ducati@zootecnista.com.br; wj_machado1@hotmail.com

2 Prof ${ }^{a}$ Associada, UNIOESTE, Marechal Cândido Rondon, PR, Brasil. E-mail: marcela.neres@unioeste.br

${ }^{3}$ Prof $^{a}$, Universidade Federal do Pampa, UNIPAMPA, Uruguaiana, RS, Brasil. E-mail: deisecastagnara@yahoo.com.br

${ }^{4}$ Prof ${ }^{a}$ Adjunta, UNIOESTE, Marechal Cândido Rondon, PR, Brasil. E-mail: edleusaseidel@yahoo.com.br

5 Discente de Mestrado do Programa de Pós Graduação em Produção Vegetal, UNIOESTE, Marechal Cândido Rondon, PR, Brasil. E-mail: jefersontpiano@hotmail.com

* Author for correspondence
} 
feno armazenado com MS abaixo de $800 \mathrm{~g} . \mathrm{kg}^{-1}$. Verificou-se que os teores de PB não diferiram entre as espécies, no entanto o tifton 85 apresentou maiores teores de PIDA, FDN e lignina. A ocorrência de fungos foi mais elevada após o armazenamento, predominando fungos do gênero Penicillium.

Palavras-chave: Avena sativa, fungos de armazenamento, Penicillium sp, proteína insolúvel em detergente neutro

\section{Introduction}

The summer pastures oversowing with winter annual species is a practice that has been adopted in some regions with the aim of improving the quality and forage production in winter, once the climate conditions favor the growth of tropical forage species only during spring/summer period with reduced quality and production in the fall/winter.

Moreira et al. (2006) defines the term oversowing to describe the practice of setting annual winter crops on a crop already formed by perennial species. This technique aims at increasing the forage production for grazing or hay production, without degrading or eliminating perennial species. According to Bertolote (2009), the implementation of this system should be in areas with irrigation or region presenting rainy winter, and one of the advantages of the oversowing technique is allow greater use of the area under cultivation.

Oats (Avena spp) is originated from ancient Asia being considered invasive plant of crops such as wheat and rye and expanded to Europe becoming an important food source for man and animals (MONTEIRO; MORAES; CORRÊA, 1996). Oats adapts to different regions of temperate and subtropical climate, being a tussock-forming species.

In oversowing systems the black oat has been the most used due to its tolerance to rust; however research conducted with white oat has shown better nutritional value of this species (NERES et al., 2011; CASTAGNARA et al., 2012) coupled with the market launch of cultivars more resistant to rust and longer cycle since most of white oat cultivars available in the market are intended for grain production.

Oliveira (2007) points out that few studies in the literature evaluates this association of summer perennial species with those annual from winter in terms of forage production, botanical composition, interaction between cultures and forage quality. Rodrigues, Avanza and Dias (2011) also high lights the need for more research in order to assess the technique.

Therefore, the objective of this work was to evaluate the oversowing technique of two oat cultivars on a field of Tifton 85, evaluating the dry matter production, dehydration curve, structural characteristics, nutritional value and fungi occurrence.

\section{Material and Methods}

The experiment was conducted on the property intended for hay production in Marechal Cândido Rondon with total production area of 30 acres of hay under the geographic coordinates $24^{\circ} 33$ '40"S latitude, 54 $04^{\prime} 12$ "'W longitude and $420 \mathrm{~m}$ altitude. The local climate according to Koppen - Geiger is Cfa type, subtropical with well distributed rainfall throughout the year and hot summers. The mean temperature of the coldest quarter varies between 17 and $18{ }^{\circ} \mathrm{C}$, between 28 and $29{ }^{\circ} \mathrm{C}$ in the hotter quarter and between 22 and $23^{\circ} \mathrm{C}$ annual. The normal mean annual total rainfall for the region ranges from 1600 to $1800 \mathrm{~mm}$, with wetter quarter presenting totals ranging from 400 to $500 \mathrm{~mm}$ (CAVIGLIONE et al, 2000).

After sowing planting winter forage by oversowing, the climate conditions were unfavorable for germination (Figure 1), requiring the irrigation of experimental area using a tank truck totaling $15 \mathrm{~mm}$ (performed on June 3, 2011) of water. There was a frost on July 5 and 6, 2011 without harming the winter species; however in 
Tifton 85 there were momentary losses through temperature rise and presence of moisture. During leaves chlorosis, but due to the presence of plants drying, climatic conditions were favorable rhizomes this species had rapid regrowth after (Figure 1, Table 1).

Figure 1. Weekly average temperatures of maximum, minimum and mean and rainfall during the months of forage growth.

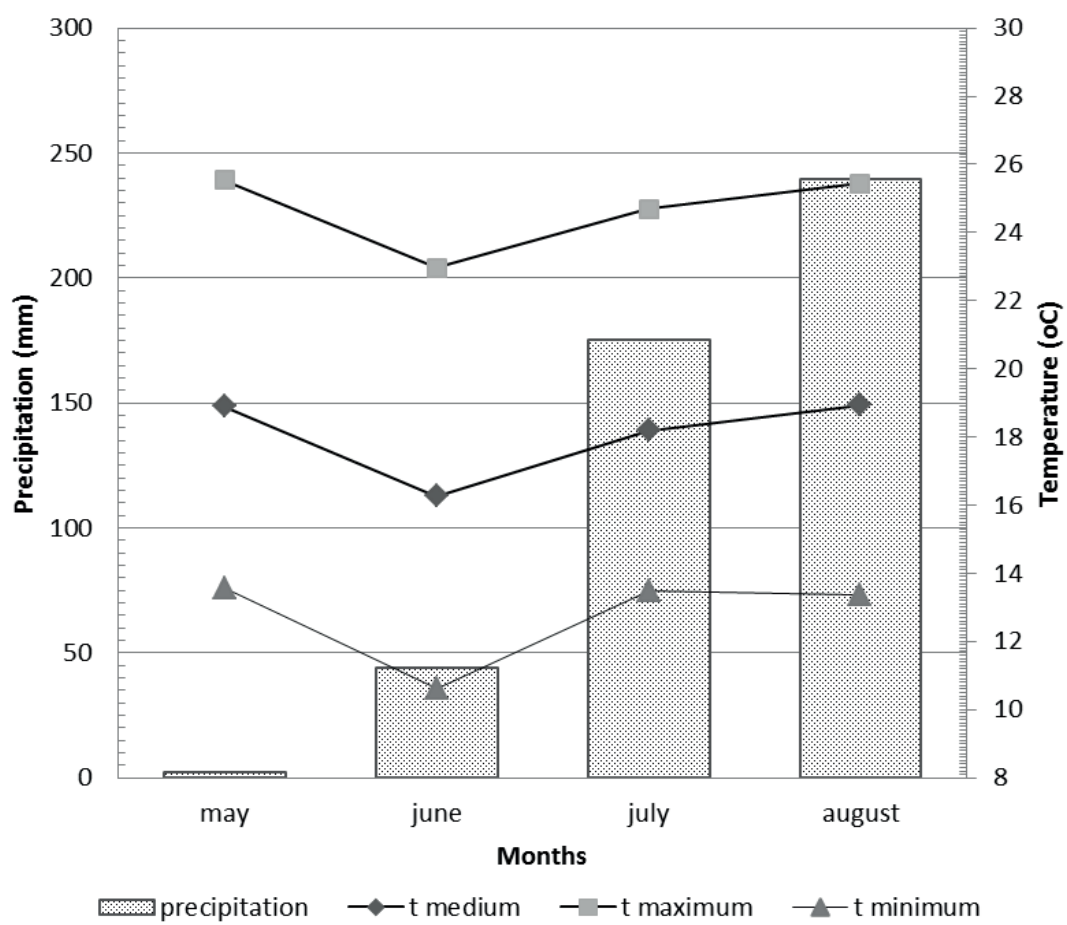

Source: Elaboration of the authors.

Table 1. Climatic data for the dates regarding the cutting and drying of Tifton 85 hay.

\begin{tabular}{lccc}
\hline \multirow{2}{*}{ Date } & \multicolumn{3}{c}{ Temperature $\left({ }^{\circ} \mathrm{C}\right)$} \\
\cline { 2 - 4 } & Mean & Maximum & Minimum \\
\hline $08 / 31 / 2011$ & 15.7 & 22.6 & 9.4 \\
$09 / 01 / 2011$ & 15.6 & 25.3 & 8.3 \\
$09 / 02 / 2011$ & 17.5 & 26.9 & 9.7 \\
\hline & \multicolumn{4}{c}{ Relative humidity $(\%)$} \\
\hline $08 / 31 / 2011$ & 56.6 & 94.0 & 23.0 \\
$09 / 01 / 2011$ & 39.6 & 59.0 & 14.0 \\
$09 / 02 / 2011$ & 46.6 & 67.0 & 20.0 \\
\hline & 5.6 & Dew point temperature $\left({ }^{\circ} \mathrm{C}\right)$ & -0.8 \\
\hline $08 / 31 / 2011$ & 0.9 & 13.6 & -4.5 \\
$09 / 01 / 2011$ & 5.0 & 4.9 & 1.8 \\
$09 / 02 / 2011$ & Radiation $\left(\mathrm{KJ} / \mathrm{m}^{2}\right)$ & Rain $/$ dew $(\mathrm{mm})$ & Wind $(\mathrm{m} / \mathrm{s})$ \\
\hline & 22463.457 & 0.0 & 5.8 \\
\hline $08 / 31 / 2011$ & 22767.210 & 0.0 & 4 \\
$09 / 01 / 2011$ & 22758.981 & 0.0 & 5.3 \\
$09 / 02 / 2011$ & & &
\end{tabular}

Source: Experimental Farm Weather Station, Marechal Candido Rondon-PR, May/August, 2011. 
The soil of the experimental area is classified as Eutroferric Red Latossol (EMBRAPA, 2006) and has the following chemical characteristics:

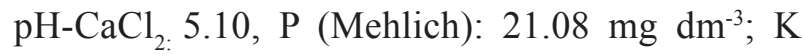
(Mehlich): $0.68 \mathrm{cmolc} \mathrm{dm}^{-3}, \mathrm{Ca}^{2+}\left(\mathrm{KCl} 1 \mathrm{~mol} \mathrm{~L}^{-1}\right)$ : $6.21 \mathrm{cmolc} \mathrm{dm}^{-3}, \mathrm{Mg}^{2+}\left(\mathrm{KCl} 1 \mathrm{~mol} \mathrm{~L}^{-1}\right): 2.22$ cmolc. $\mathrm{dm}^{-3} ; \mathrm{Al}^{3+}\left(\mathrm{KCl} \mathrm{L}^{-1} \mathrm{~mol} \mathrm{~L}^{-1}\right): .00 \mathrm{cmolc} \mathrm{dm}^{-3} ; \mathrm{H}+\mathrm{Al}$ (ethyl $0.5 \mathrm{~mol} \mathrm{~L}^{-1}$ ): 3.97 cmolc $\mathrm{dm}^{-3}$, SB: 9.11 cmolc dm ${ }^{-3}$; CTC: 13.08 cmolc dm ${ }^{-3} \mathrm{~V}$ : $6965 \%$; organic matter (method Boyocus): $25.97 \mathrm{~g} \mathrm{dm}^{-3}$; $\mathrm{Cu}: 14.70 \mathrm{mg} \mathrm{dm}^{-3}$; Zn: $10.40 \mathrm{mg} \mathrm{dm}^{-3}$, Mn: 181.00 $\mathrm{mg} \mathrm{dm}{ }^{-3}$; Fe: $23.20 \mathrm{mg} \mathrm{dm}^{-3}$. The experiment was carried out in a field of Cynodon sp cv. Tifton 85 deployed for 6 years, with an area of 4.0 ha and it is intended only for hay production to marketing, which regularly receives swine slurry in the amount of $500 \mathrm{~m}^{3} \mathrm{ha}^{-1}$ year. In the manure analysis it was detected: Methodology flame AAS N: $1.75 \mathrm{~g}$ $\mathrm{kg}^{-1}$, P: $0.06 \mathrm{~g} \mathrm{~kg}^{-1}, \mathrm{~K}: 0.10 \mathrm{~g} \mathrm{~kg}^{-1}, \mathrm{Ca}: 3.30 \mathrm{~g} \mathrm{~kg}^{-1}$; Mg: $1.00 \mathrm{~g} \mathrm{~kg}^{-1}, \mathrm{Cu}: 1.00 \mathrm{mg} \mathrm{kg}^{-1}$, Fe: $2.00 \mathrm{mg} \mathrm{kg}^{-1}$, Mn: ND (not detected); Zn: $2.00 \mathrm{mg} \mathrm{kg}^{-1}$.

The experimental design was randomized blocks with split-plot overtime, three tillage systems and three times of assessment with 5 repetitions: Tifton 85 single; Tifton 85 with long-cycle oat oversowing (Avena sativa IPR 126); Tifton 85 with white oat oversowing for grains (Avena sativa Guapa)

Sowing of winter forage was performed on octuber $5^{\text {th }}, 2011$, immediately after cutting the Tifton 85 for haymaking. $80 \mathrm{~kg} \mathrm{ha}^{-1}$ of white oat seeds of each species was used. For sowing, a precision seeder by tractor for tillage with spacing of $0.17 \mathrm{~m}$ between rows, was used. The width of the plots corresponded to 4 passes of the tractor $(2.38$ $\mathrm{m}$ wide) totaling $9.52 \mathrm{~m}$ to $30 \mathrm{~m}$ in length, with a total area of $285.6 \mathrm{~m}^{2}$. The germination of the plants was between 6 and June 8 and the urea application occurred on 06/15 with the dosages used: $100 \mathrm{~kg}$ $\mathrm{ha}^{-1}$ of nitrogen as urea ( $45 \%$ nitrogen).

The hay cut in the experimental field was carried out on August, 31, at $11 \mathrm{~h} 00$ am after drying the dew with a mower conditioner by tractor, endowed with nylon free fingers for plant's mechanical conditioning (folding) at height of $5 \mathrm{~cm}$ above the soil. After cutting and mechanical conditioning, the forage remained in the field, exposed to the sun for dehydration. The baling occurred on September 1 at 3h00 afternoon. All treatments were made of rectangular bales with $10 \mathrm{~kg}$ mean weight. In the study of the dehydration curve, the experimental design was a randomized block with split-plot overtime being allotted in the plots three cropping systems and five sampling times and five replications in the sub plots. The sampling times corresponded to the following days and times of the dehydration period: $1^{\text {st }}$ day (cut day): (0 time) $11 \mathrm{~h} 00$ (time 6) 17h00, $2^{\text {nd }}$ day: time (21) 08h00 (time 25) $12 \mathrm{~h} 00$ (time 30) 17h00. After sampling each time the hay was stored in paper bags and subjected to drying in an oven with forced air for 72 hours at $55^{\circ} \mathrm{C}$ for dry matter (DM) determination. From DM contents were obtained the dehydration curves.

The samples for determination of dehydration curves were performed at $8 \mathrm{~h} 00,12 \mathrm{~h} 00$ and 17 h00 hours each day by collecting samples of approximately $300 \mathrm{~g}$ in each plot. After sampling, the samples were packed in paper bags and dried in an oven with forced air circulation at $65^{\circ} \mathrm{C}$ for dry matter determination. Structural characteristics evaluation was performed as follows: for plants canopy height were collected measures at 10 points in each plot, with a graduated scale of $100 \mathrm{~cm}$. In obtaining the stem diameter were taken 20 tillers and a caliper positioned before the first node. To determine the leaf / stem ratio, it was used the method of manual separation and drying, in which samples of $50 \mathrm{~g}$ were collected and separated into leaves and stems, which were placed in paper bags and submitted to drying at a temperature of $55^{\circ} \mathrm{C}$ for 72 hours in oven with forced ventilation. The leaf / stem ratio $(\mathrm{F} / \mathrm{C})$ was obtained from the ratio of the dry weight of leaves and dry weight of the stems.

The chemical composition of the hay was studied in a complete randomized block design in 
a split plot overtime with 3 treatments allocated to plots and three times in the subplots: cutting, baling and 30 days of hay storage, with 5 repetitions. In the shed storage, hay was housed in masonry airy shed, covered with clay tiles, brick-floored, where hay was arranged in stacks on wooden pallets with a height of $10 \mathrm{~cm}$ from the floor. In stored hay, the bales were opened for sampling at 30 days of storage. At the time of sampling, samples were collected for dry matter determination and fungi occurrence.

For dry matter content and chemical composition, samples of $300 \mathrm{~g}$ were collected, which were packed in paper bags and dried in an oven with forced air for 72 hours at $55^{\circ} \mathrm{C}$. After drying the samples were ground in a Wiley type mill with $1 \mathrm{~mm}$ sieve and subjected to laboratory procedures for determination of crude protein (CP) according to AOAC (1990), neutral detergent fiber (NDF), acid detergent fiber (ADF) according to Van Soest and Robertson (1985), neutral detergent insoluble protein (NDIP, expressed in $\mathrm{g} \mathrm{kg}$ of $\mathrm{CP}$ ), acid detergent insoluble protein (ADIP, expressed in $\mathrm{g} \mathrm{kg}^{-1}$ of $\mathrm{CP}$ ), lignin (LAS) according to the methodology developed by Van Soest (1965), and hemicellulose and cellulose (SILVA; QUEIROZ, 2006).

The fungi were isolated by induction of mycelial growth in BDA culture medium by induced sporulation or directisolation of signals (reproductive structures) of the pathogen from samples collected (FERNANDEZ, 1993; MENEZES; SILVAHANLIN, 1997). Dilutions ranged from $10^{1}$ to $10^{5}$ and after incubation the colonies were counted using a Quebec colony counter being able to be counted the plates with 30 and $300 \mathrm{CFU}$ (Colony Forming Unit) per Petri dish and the results in this assay were considered in $10^{1}$ dilution.

From microscopic observation (stereoscope microscope), semi-permanent slides were prepared of all fungal structures found in both symptomatic materials and culture medium. These structures were transferred with the aid of a needle or stylus to a microscope slide with dye lactophenol blue cotton, covered with coverslip, sealed with enamel and observed under optical microscopy to identify the fungus, with the aid of specific identification keys (BARNETT; HUNTER, 1987; CARMICHAEL et al., 1980; GUARRO; GENÉ; STCHIGEL, 1999; SAMSON et al., 1995). The experimental design for the occurrence of fungi was a randomized block with split-plot overtime, three cropping systems and two collection times (cutting and storage).

During the storage period were monitored the room temperature in the shed and temperature $\left({ }^{\circ} \mathrm{C}\right)$ of bales by taking 3 points in each bale; being monitored 5 bales per treatment with skewer-type digital thermometer. Based on the observed data, the graph of temperature oscillation and temperature of the bales in the shed was elaborated.

Data were subjected to analysis of variance, and when found significance by the F test, the dry matter contents throughout the period of dehydration were studied by means of regression analysis, with the choice of the model that presented minimum significance of $5 \%$ by the $T$ test and higher coefficient of determination $\left(\mathrm{R}^{2}\right)$. The structural characteristics, dry matter yield, bromatological composition were compared by the Tukey test at $5 \%$ probability.

The fungi discussion was based with descriptive analyses.

\section{Results and Discussion}

The higher dry matter production was observed in Tifton 85 single $(\mathrm{P}<0.05)$ surpassing the production of associations Tifton $85+$ white oat (Table 2), as annual crops oversowing showed low yield due to low rainfall (May to June) in the establishment period (Figure 1) impairing the production of total dry matter of the association $(789.20 \mathrm{~g} \mathrm{~kg}$ $\mathrm{ha}^{-1}$ of IPR 126 and $1180.00 \mathrm{~g} \mathrm{~kg} \mathrm{ha}^{-1}$ ). The low initial precipitation was reflected throughout the crop development, showing that the success in implementing this system depends not only on 
chemical attributes in the soil and seed quality, but favorable weather conditions or use of the irrigation system. The reduced growth of Tifton 85 when combined with oats was also certified by Neres et al. (2011), but according to the data obtained by the author, the oats in association with Tifton 85 promotes the increased nutritional value of forage intended to hay production.

Table 2. Dry matter production and structural characteristics of Tifton 85 and association with white oat.

\begin{tabular}{lcccc}
\hline \multicolumn{1}{c}{ Treatments } & $\begin{array}{c}\text { DM production } \\
\left(\mathrm{kg} \mathrm{ha}^{-1}\right)\end{array}$ & $\begin{array}{c}\text { Plants Height } \\
(\mathrm{cm})\end{array}$ & F/C & $\begin{array}{c}\text { Stem diameter } \\
(\mathrm{mm})\end{array}$ \\
\hline Tifton 85 & $3550.60 \mathrm{a}$ & $16.75 \mathrm{c}$ & $0.99 \mathrm{~b}$ & $1.44 \mathrm{bc}$ \\
Tifton 85 + IPR 126 & $2625.80 \mathrm{~b}$ & ---- & ---- & ---- \\
Tifton 85+ Guapa & $3021.80 \mathrm{ab}$ & ---- & ---- & ---- \\
IPR 126 (tifton 85) & $789.20 \mathrm{~d}$ & $31.20 \mathrm{~b}$ & $1.11 \mathrm{a}$ & $1.76 \mathrm{~b}$ \\
Guapa (tifton 85) & $1180.80 \mathrm{dc}$ & $46.40 \mathrm{a}$ & $0.77 \mathrm{c}$ & $2.96 \mathrm{a}$ \\
Tifton 85 (IPR) & $1828.00 \mathrm{c}$ & $14.60 \mathrm{c}$ & $1.02 \mathrm{ab}$ & $1.16 \mathrm{c}$ \\
Tifton 85 (Guapa) & $1841.60 \mathrm{c}$ & $16.60 \mathrm{c}$ & $1.05 \mathrm{ab}$ & $1.48 \mathrm{bc}$ \\
CV (\%) & 16.88 & 14.64 & 4.93 & 26.51 \\
\hline
\end{tabular}

* Means followed by the same letter in the column do not differ by the Tukey test at $5 \%$ probability.

Tifton 85: Tifton 85; Tifton 85 + IPR 126: Tifton 85 oversowing with white oat IPR 126, Tifton 85 + Guapa: Tifton 85 oversowing with Guapa white oat.

Source: Elaboration of the authors.

The canopy heights were higher in oats (Table 2) according to the cespitose size because Tifton 85 has to be some estolonipherous species with keeper growth. The white oat IPR 126 Iapar launch in 2005 with suitability for grazing and long cycle has a characteristic of semi-prostate growth habit, thus presenting height of $31.30 \mathrm{~cm}$ compared to white oat guapa $(46.40 \mathrm{~cm})$ with cespitose growth habit. The Tifton 85 single and in combination showed no differences between heights averaging $15.98 \mathrm{~cm}$.

The leaf/stem ratio of IPR 126 was the highest one $(1.11 \mathrm{P}<0.05)$ and that of Guapa was lowest ratio 0.77 . The variable stem diameter is also one of important features in the dehydration process for producing hay fodder, since the larger the diameter, the greater the time required for dehydration. The stem diameter ranged between Tifton 85 and the oat cultivars with higher values in Guapa (2.96 $\mathrm{mm})$ followed by IPR $126(1.75 \mathrm{~mm})$, being advised the use of conditioners in these cultivars, which, by causing injuries in the stem, accelerate the rate of dehydration. Stem diameter in Tifton 85 ranged from 1.16 to $1.48 \mathrm{~mm}$ and these values were considered ideal for a high rate of dehydration. The Tifton 85 had higher DM content (Figure 2) at cutting (378.06 $\mathrm{g} \mathrm{kg}^{-1}$ ) regarding the associations, which can be explained by the higher water content present in oats.

Tifton 85 and the association Tifton $85+$ IPR 126 reached appropriate DM levels at the time of baling thus avoiding increasing the risk of DM losses, higher incidence of fungi and elevations of neutral detergent insoluble protein. However, the cultivation Tifton $85+$ guapa in baling showed $775.06 \mathrm{~g} \mathrm{~kg}^{-1}$, DM levels which increased after 30 days of storage. 
Figure 2. Dry matter $(\hat{Y})$ of hay Tifton $85(\diamond)$, Tifton 85 oversowing with IPR 126 white oat (घ) and Tifton 85 oversowing with guapa white oat $(\mathbf{\Delta})$ as depending on the drying time.

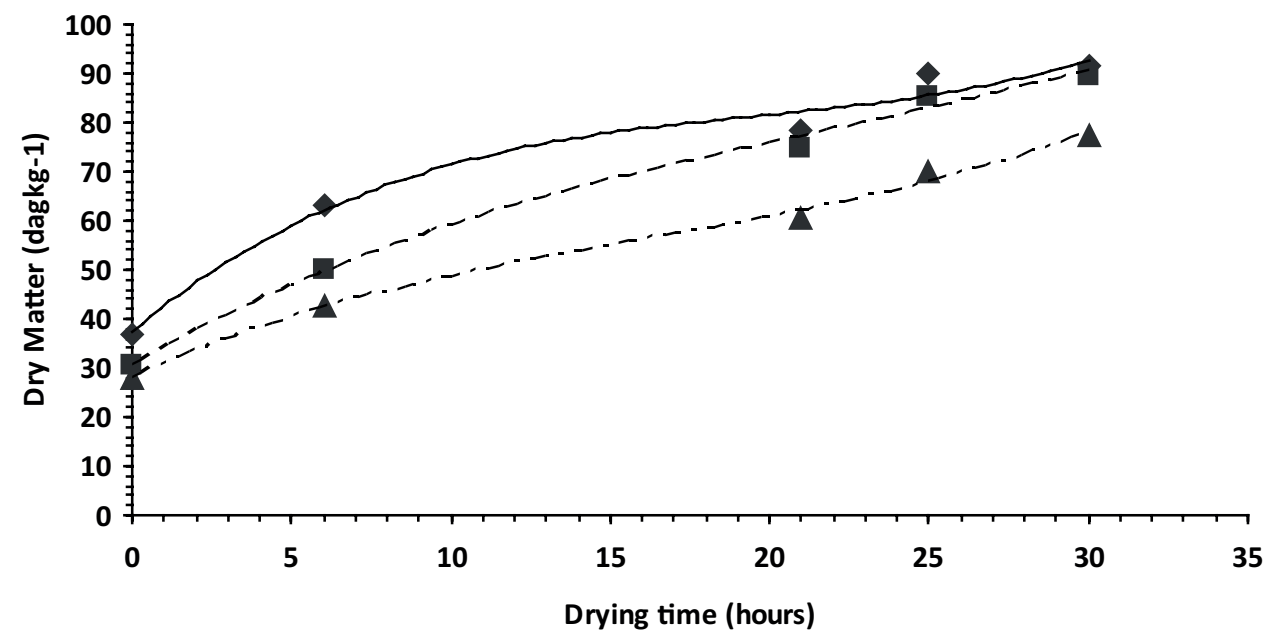

Source: Elaboration of the authors.

The crude protein contents did not differ between crops at cutting (Table 3 ), being lower than the expected in white oat + Tifton 85 , once the white oat stands out for the high CP content and lower NDF and ADF. Neres et al. (2012), when evaluating the IPR 126 white oat under grazing obtained 230.7 g.kg ${ }^{-1}$ CP, 529.8 g. $\mathrm{kg}^{-1}$ NDF and 303.7 g kg-1 ADF $^{-1}$ in the first grazing. These low fiber contents can be attributed to the low development of white oat in the year assessed. Values of fiber increased in baling and storage. The neutral detergent insoluble protein did not differ between cropping systems in cutting and baling, but the Tifton 85 had higher levels in the storage $(\mathrm{P}<0.05)$ compared to the other treatments, showing that the hay undergoes changes in its composition. The acid detergent insoluble protein did not differ among cultures but it increased during baling in Tifton 85 hay $(\mathrm{P}<0.05)$ also remained in the storage. When compared to the steps, there was increased from cutting to baling and to storage.

There were no significant differences between the crops in cutting but this reduced in the treatment Tifton $85+$ IPR in baling and in Tifton 85 during storage. The opposite was observed with the hemicellulose that increased in Tifton 85 single and reduced in associations in the baling and storage. Lignin contents were higher in Tifton 85 single at the time of cutting and storage. Concerning to steps, there was increased lignin in Tifton 85 from cutting to storage. 


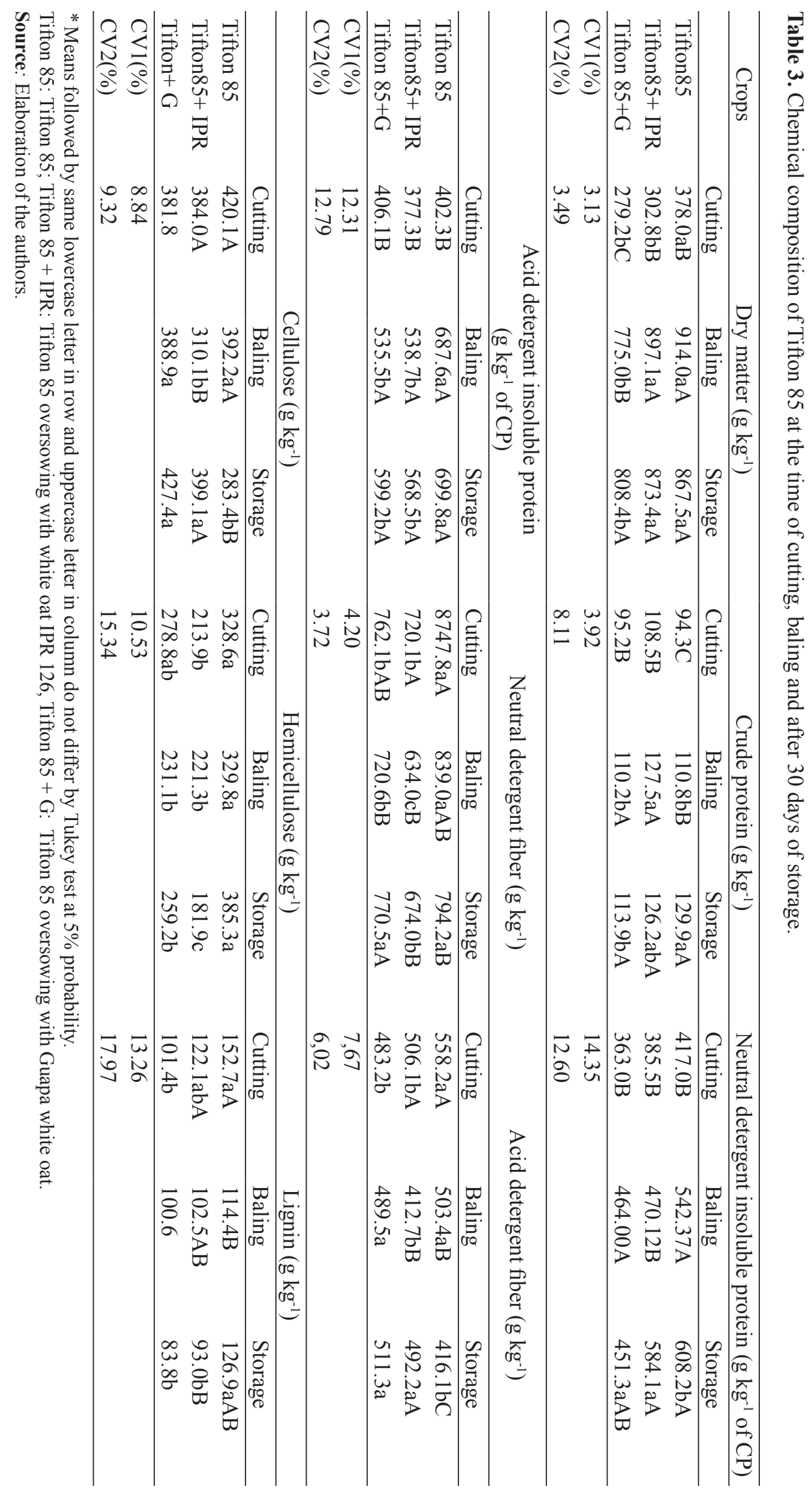


The bales monitored during storage showed oscillations depending on the room temperature (Figure 3) and the treatments of grass Tifton 85 + Guapa presented temperature above room temperature at the 5th, 7th and 8th day, which may be due to the higher moisture content in time of baling. After the first week there were no peaks of rising temperatures of bales compared to the room temperature.

Figure 3. Values of room temperature inside the storage shed and temperatures of hay bales of Tifton 85 single and Tifton 85 with white oats.
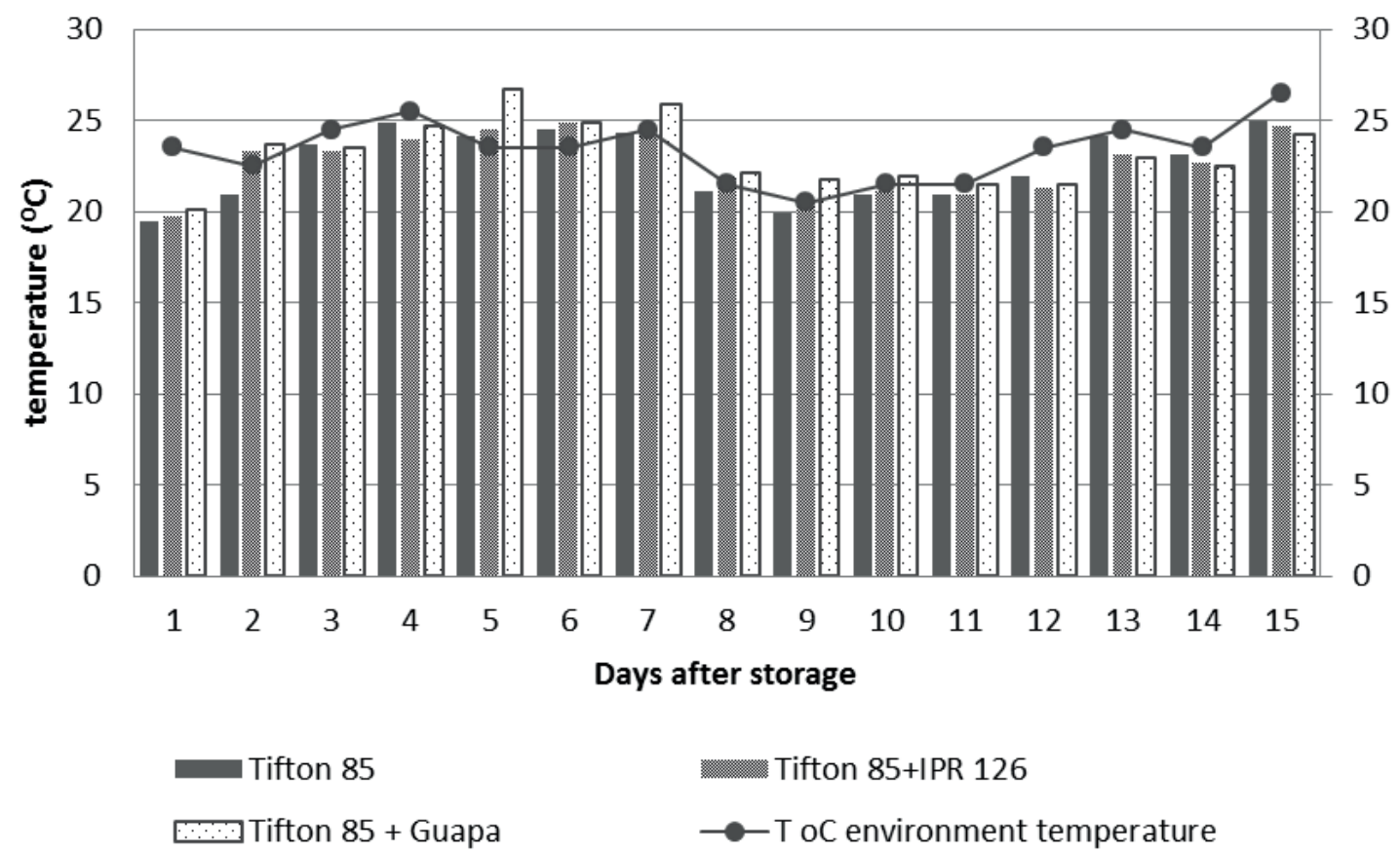

-

$\longrightarrow$ T oC environment temperature

Source: Elaboration of the authors.

The population of fungi was higher in storage when compared with the cutting (Figure 4). The genera that prevailed at the cutting were Phoma and Fusarium being typical field fungi (Figure 5). 
Figure 4. Total count of fungi before cutting and after 30 days of hay storage.

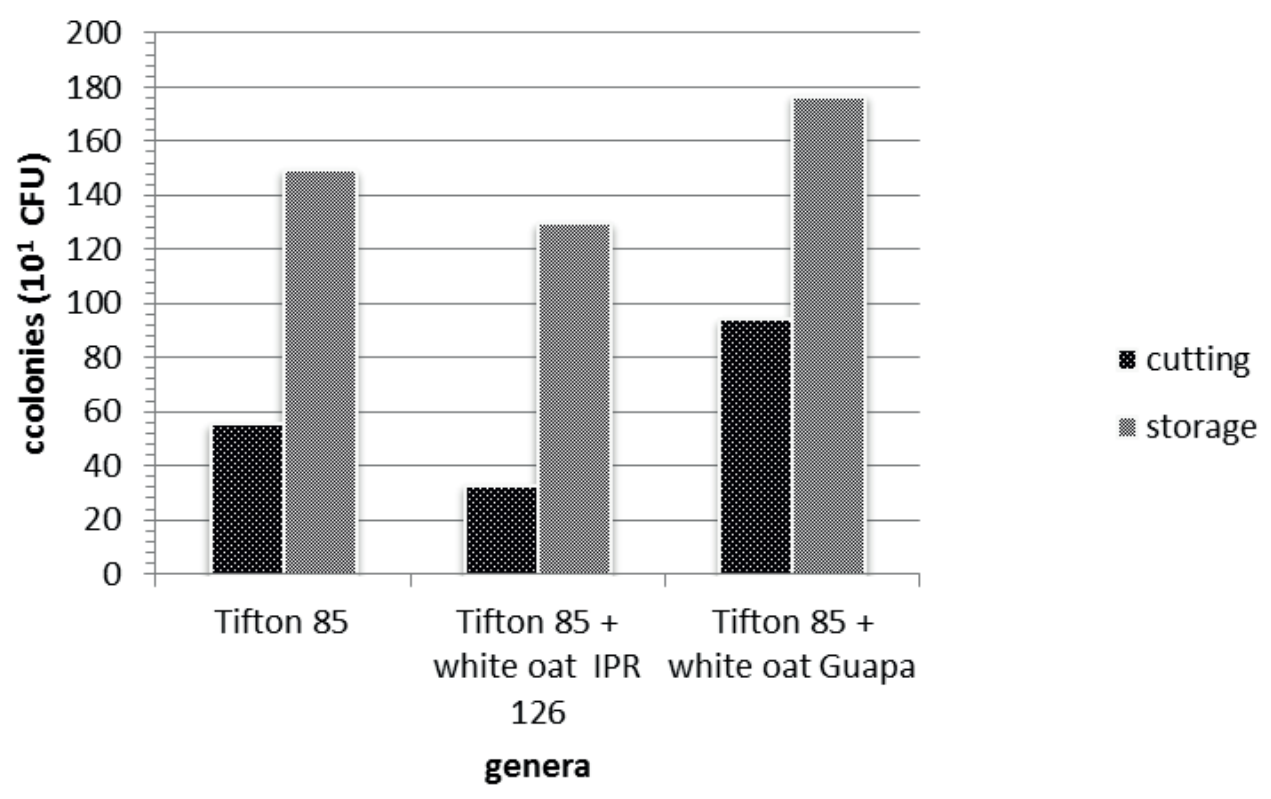

Source: Elaboration of the authors.

After storage the most common species of fungi genera were Penicillium, fungus typical of storage, followed by the genus Phoma and Cladosporium and, in the treatment Tifton $85+$ Guapa also
Diplococcium (Figure 6). In the treatment Tifton 85 + Guapa there was predominance of Cladosporium compared to Penicillium and in all treatments there was low occurrence of Aspergillus.

Figure 5. Count colonies of fungal genera present $\left(\mathrm{CFU} \mathrm{g} 10^{1}\right)$ before cutting the forage.

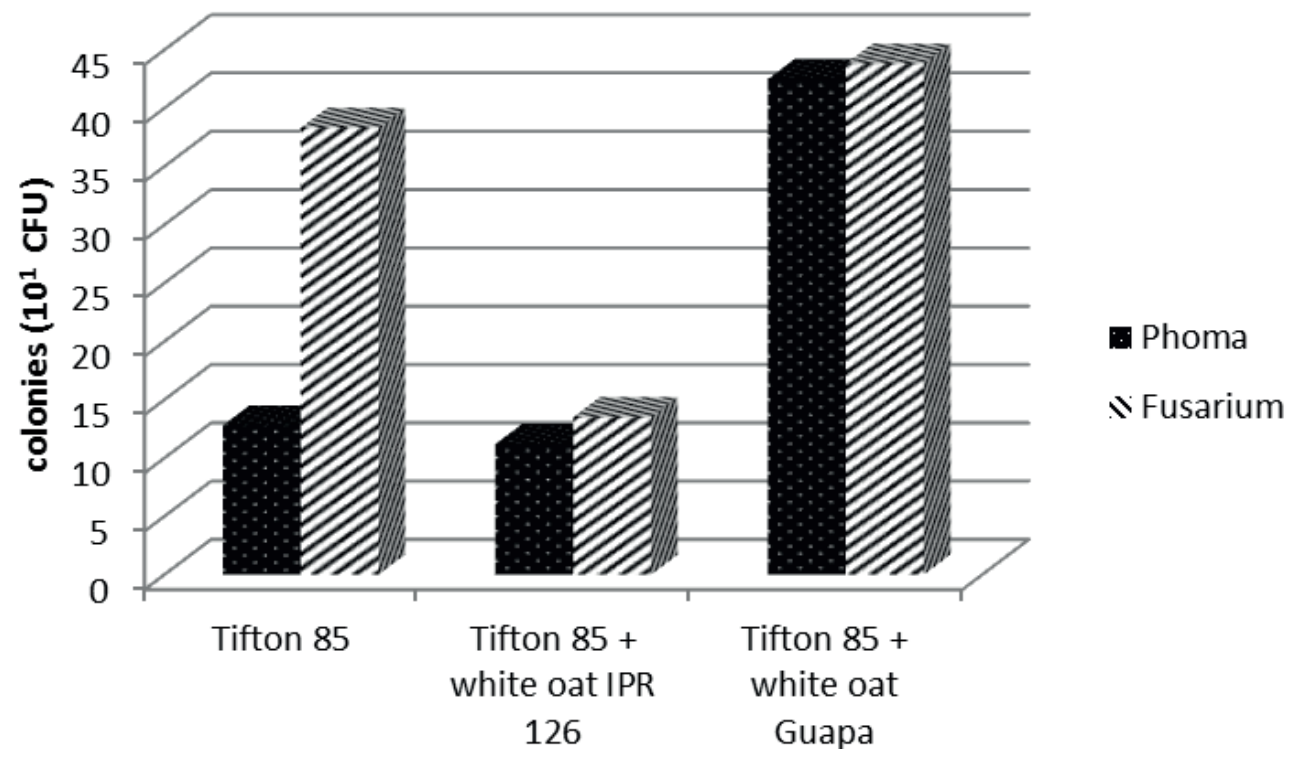

Source: Elaboration of the authors. 
Figure 6. Count of fungi genera $(\mathrm{CFU}$ g10 $)$ in Tifton 85 hay 30 days after storage.

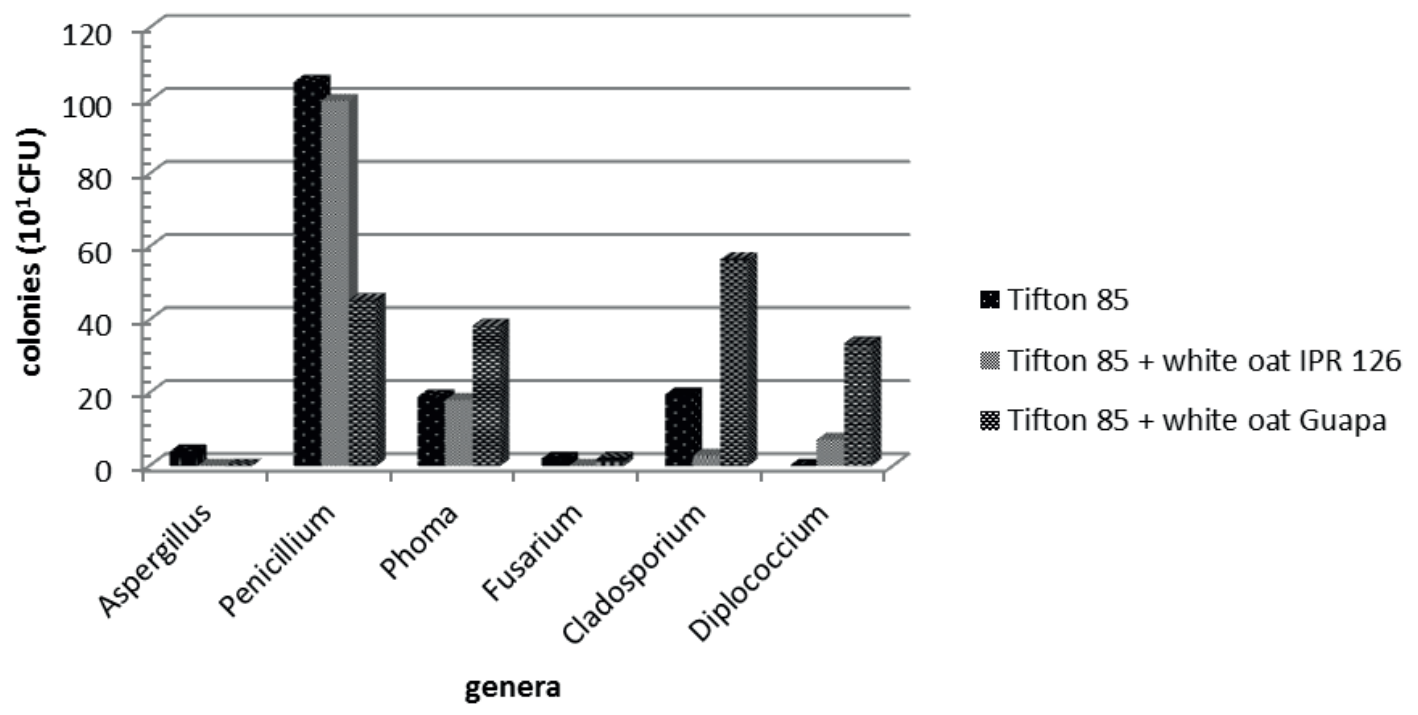

Source: Elaboration of the authors.

\section{Conclusions}

The success of oversowing cool season species in areas of production of Tifton 85 hay depends on climatic factors prevailing in the year. The oat oversowing in areas of Tifton 85 does not increase the dry matter production, but further improvements in the nutritional value of the hay produced with lower neutral detergent fiber and lignin contents.

The occurrence of fungi in hay stored with suitable levels of dry matter should be further studied in view of the occurrence of the genus Penicillium.

\section{References}

ASSOCIATION OF OFFICIAL ANALYTICAL CHEMISTS - AOAC. Official methods of analysis. 15. ed. Virginia: Arlington. 1990, $1117 \mathrm{p}$.

BARNETT, H. L.; HUNTER, B. B. Illustrated genera of imperfect fungi. New York: Macmillan Publishing Company, 1987. 218 p.

Bertolote, L. E. M. Densidade de semeadura de aveia e altura de corte da pastagem de capim Tanzânia sobressemeada. 2009. Dissertação (Mestrado em Nutrição e Produção Animal) - Universidade Estadual Paulista, Campus de Botucatu, Botucatu.
CARMICHAEL, J. W.; KENDRICK, W. B.; CONNERS, I. L.; SIGLE, L. Genera of Hyphomycetes. Manitoba: Hignell Printing, 1980. 386 p.

CASTAGNARA, D. D.; NERES, M. A.; OLIVEIRA, P. S. R.; JOBIM, C. C.; TRES, T. T.; MESQUITA, E. E.; ZAMBOM, M. A. Use of a conditioning unit at the haymaking of Tifton 85 oversowing with Avena sativa or Lolium multiflorum. Revista Brasileira de Zootecnia, Viçosa, MG, v. 41, n. 6, p. 1353-1359, 2012.

CAVIGLIONE, J. H.; KIIHL, L. R. B.; CARAMORI, P. H.; OlIVEIRA, D. Cartas climáticas do Paraná. Londrina: IAPAR, 2000. CD-ROM.

EMPRESA BRASILEIRA DE PESQUISA AGROPECUÁRIA - EMBRAPA. Centro Nacional de Pesquisa de Solos. Manual de métodos de análise de solo. 2. ed. Rio de Janeiro, 2006. 212 p.

FERNANDEZ, M. R. Manual para laboratório de fitopatologia. Passo Fundo: EMBRAPA-CNPT, 1993. $128 \mathrm{p}$.

GUARRO, J.; GENÉ, J.; STCHIGEL, A. M. Developments in fungal taxonomy. Clinical Microbiology Reviews, Washington, v. 12, n. 3, p. 454-500, 1999.

MENEZES, M.; SILVA-HALIN, D. M. W. Guia prático para fungos fitopatogênicos. Recife: UFRPE, 1997. 106 p.

MONTEIRO, A. L. G.; MORAES, A.; CORRÊA, E. A. S. Forragicultura no Paraná. Londrina: Comissão 
Paranaense de Avaliação de Forrageiras CPAF, 1996. $305 \mathrm{p}$.

MOREIRA, A. L.; REIS, R. A.; SIMILI, F. F.; PEDREIRA, M. S.; CONTATO, E. D.; RUGGIERI, A. C. Época de sobressemeadura de gramíneas anuais de inverno e de verão no capim Tifton 85: valor nutritivo. Ciência e Agrotecnologia, Lavras, v. 30, n. 2, p. 335-343, 2006.

NERES, M. A.; CASTAGNARA, D. D.; MESQUITA, E. E.; JOBIM, C. C.; TRÊS, T. T.; OLIVEIRA, P. S. R.; OLIVEIRA, A. A. M. A. Production of Tifton 85 hay oversowing with white oats or ryegrass. Revista Brasileira de Zootecnia, Viçosa, MG, v. 40, n. 8, p. 16381644, 2011.

NERES, M. A.; CASTAGNARA, D. D.; OLIVEIRA, P. S. R.; OLIVEIRA, E.; JOBIM, C. C.; TRÊS, T. T.; MESQUITA, E. E. IPR 126 white oat forage potential under free growth, cutting and grazing at two management height. Revista Brasileira de Zootecnia, Viçosa, MG, v. 41, n. 4, p. 889-897, 2012.
OLIVEIRA, P. P. A. Produção de forragem e composição botânica de três espécies de pastagens tropicais sobressemeadas com aveia ou azevém. In: REUNIÃO ANUAL DA SOCIEDADE BRASILEIRA DE ZOOTECNIA, 44., 2007, Jaboticabal. Anais... Jaboticabal: UNESP, 2007. CD-ROM.

RODRIGUES, D. A.; AVANZA, M. F. B; DIAS, L. G. G. G. Sobressemeadura de aveia e azevém em pastagens tropicais no inverno: revisão de literatura. Revista Científica Eletrônica de Medicina Veterinária, Garça, v. 1, n. 16, p. 1-22, 2011.

SAMSON, R. A.; HOEKSTRA, E. S.; FRISVAD, J. C.; FILTENBORG, O. Introduction to food borne fungi. $4^{\text {th }}$ ed. Netherlands: Beam, 1995. 322 p.

SILVA, D. J.; QUEIROZ, A. C. Análise de alimentos: métodos químicos e biológicos. Viçosa: Ed. UFV, 2006. $235 \mathrm{p}$.

VAN SOEST, P. J. Voluntary intake relation to chemical composition and digestibility. Journal of Animal Science, Champaign, v. 24, n. 3, p. 834-844, 1965.

VAN SOEST, P. J.; ROBERTSON, J. B. Analysis of forage and fibrous foods. Ithaca: Cornell University, 1985. $202 \mathrm{p}$. 